\title{
Non-obstetric vaginal trauma
}

\author{
Ian S. C. Jones ${ }^{1}$, Alan O'Connor ${ }^{2}$ \\ ${ }^{1}$ Medical Director, Women's and Newborn Services, Royal Brisbane and Women’s Hospital, University of Queensland, Brisbane, Australia \\ ${ }^{2}$ Medical Director, Department of Emergency Medicine, Royal Brisbane and Women’s Hospital, Queensland University of Technology, \\ Brisbane, Australia \\ Email: ian_jones@health.qld.gov.au
}

Received 2 October 2012; revised 5 November 2012; accepted 15 November 2012

\begin{abstract}
Objective: To describe the mechanism, injury pattern and management of women who present to the Emergency Department with non-obstetric vaginal trauma. Methods: A retrospective, single institution case series was carried out. Data was sourced from medical records of women who presented to the Emergency Department and Royal Brisbane and Women's Hospital between 2007 and 2011. Records of possible injuries to the vagina were assessed to determine incidence, age, site, type of injury, mechanism of injury and whether urinary retention required treatment. Results: Vaginal non-obstetric trauma was found in 11 of 519 cases resulting in lacerations or tears. Injuries were due to consensual coitus, other forms of sexual activity and self harm. Acute urinary retention did not occur in any case but two cases required resuscitation. Site of injury was most common high in the vagina. Conclusion: Non-obstetric vaginal injuries are uncommon (incidence $\mathbf{2 . 1 \%}$ ). All cases require assessment for vulvar, vaginal, urethral, anal and bony pelvis injuries. This may require examination under anaesthesia. Social worker and psychological support is important to reduce the incidence of long-term psychological problems.
\end{abstract}

Keywords: Non-Obstetric; Vaginal; Trauma; Diagnosis; Management

\section{INTRODUCTION}

Direct vaginal trauma is an uncommon injury, but one which can have significant short and long term physical and psychological consequences [1]. Compared to obstetric causes of vaginal trauma non-obstetric trauma is very uncommon. In most cases it is caused by direct blunt trauma to an area containing a rich vascular network. Types of trauma reported by others include vigorous consensual and non-consensual coital injury, physical assault $[2,3]$ and genital self mutilation $[4,5]$.
The present study sought to review the Emergency Department (ED) records of women presenting with nonobstetric vaginal trauma, determine the incidence, age distribution, site and type of injury, mechanism of injury and whether acute urinary retention required treatment.

\section{METHODS}

The Royal Brisbane and Women's Hospital is a 900 plus bed tertiary hospital based at Herston. The Emergency Department (ED) sees 74,000 adult patients per year including all those patients requesting assessment following alleged sexual assault. The hospital Emergency Department Information System (EDIS) records of women who presented to the Royal Brisbane and Women's Hospital Emergency Department for the five years between 2007 and 2011 with possible injuries to the vulva and vagina were assessed. All such patients would present and be admitted through the ED. The search of EDIS listed all initial female ED presentations with ICD 10 codes S31.4, T74.2, T19.2 and 9039 during the time period 2007 to 2011. For those cases where physical injury to the vagina was documented in the Emergency Department records the hospital admission records were then reviewed in detail to determine the age distribution, site and type of injury, mechanism of injury, whether urinary retention required treatment and the type of wound treatment given. This information (age distribution, site and mechanism of injury and type of wound treatment given) was reviewed and analysed manually.

Ethics approval for the review of case records was obtained from the Clinical Research Ethics Committee of the Royal Brisbane and Women's Hospital.

\section{RESULTS}

There were 519 cases of women presenting with conditions where there was a mechanism that raised the possibility of a non-obstetric vulvo-vaginal injury. Eleven cases (2.1\%) were discovered to have vaginal tears. Each of these cases required admission for assessment and 
management. Of the 519 cases 362 (70\%) presented because of alleged sexual abuse or alleged rape and 82 others presented for removal of vaginal foreign bodies (16\%). Bleeding due to lower genital tract infection was present in 51 cases and 13 patients did not wait for assessment. The description of the injury was made by the ED registrar or the gynaecology registrar. Patient ages ranged from 20 to 40 years and all had had previous coital experience. The mechanism of injury was consensual coitus (seven cases), self harm with foreign bodies (two cases) and from fisting and inserting a foreign body (one each). One case of self harm had been admitted on four separate occasions with vaginal foreign bodies between 2004 and 2011 and on four other occasions with foreign bodies in the rectum which on one occasion required a laparotomy to remove the object from the colon. There were no cases of acute urinary retention. The extent of the injuries ranged in size from 1 to $5 \mathrm{~cm}$ (Table 1). Treatments were described as conservative or surgical. Conservative treatment was admission and observation only and surgical treatment included Examination Under Anaesthesia (EUA), suturing wounds under general anaesthesia in an operating theatre, laparoscopy to check for organ damage and laparoscopic removal of a foreign body and drainage of an infected intra-abdominal haematoma. Two patients required a blood transfusion and another who had the infected intra-abdominal haematoma drained laparoscopically received antibiotics. None of the 11 cases had associated non-genital injuries.

\section{DISCUSSION}

This study confirms that non-obstetric vaginal injuries are uncommon. Such injuries usually result from coitus which is in agreement with others [6]. Sloin, Karimian and Ilbeigi (2006) suggested predisposing factors that may result in such injuries include virginity, disproportion of male and female genitalia, atrophic vagina in postmenopausal women, friability of tissues, stenosis and scarring of the vagina because of congenital abnormalities, previous surgery, or pelvic radiation therapy. Other factors suggested by them included rough and violent thrusting of the penis during intercourse, insertion of foreign bodies, and sexual assault [7]. Self mutilation occurred in two of our cases with each case having a long history of sexual abuse, findings which are in agreement with others $[4,5]$. Non-coital vaginal injuries may result from pelvic fractures and blunt or penetrating abdominal trauma [7], however this study did not encounter any such injuries.

In the current series the anatomical locations for injuries were in the posterior fornix or lateral vaginal walls. In our series five cases of consensual coitus resulted in such an injury.

Diagnosis would appear to be straightforward but does require a vaginal speculum examination. The extent of

Table 1. Non obstetric vaginal trauma.

\begin{tabular}{|c|c|c|c|c|c|c|}
\hline $\begin{array}{l}\text { Unit record number/year } \\
\text { of presentation }\end{array}$ & Age & $\begin{array}{l}\text { Mechanism of } \\
\text { injury/parity }\end{array}$ & Injury & $\begin{array}{l}\text { Site of vaginal } \\
\text { injury }\end{array}$ & $\begin{array}{l}\text { Size of injury } \\
\mathrm{cm} / \text { shock }\end{array}$ & Surgical treatment/sutures \\
\hline $1917052 / 2011$ & 23 & Coitus/0 & Tear & $\begin{array}{l}\text { Posterior } \\
\text { fornix }\end{array}$ & 3/nil & Surgical/5 sutures \\
\hline $1139266 / 2008$ & 31 & $\begin{array}{c}\text { Self harm-Mental } \\
\text { illness } / 0\end{array}$ & $\begin{array}{c}\text { Tear-14 cm pencil } \\
\text { into vagina entered } \\
\text { peritoneum }\end{array}$ & $\begin{array}{l}\text { Posterior } \\
\text { fornix }\end{array}$ & 1/nil & $\begin{array}{c}\text { Laparoscopy } \\
\text { Infected haematoma drained } \\
\text { No vaginal sutures }\end{array}$ \\
\hline $1947197 / 2010$ & 39 & $\begin{array}{c}\text { Fisting on asprin for } \\
\text { SVT/4 }\end{array}$ & Tears & $\begin{array}{c}\text { Bilateral } \\
\text { vagina }\end{array}$ & $\begin{array}{l}\text { Two wounds }-4 \& \\
5 \mathrm{~cm} / \text { shocked }\end{array}$ & Multiple sutures \\
\hline B947667/2010 & 40 & Coitus/2 & Tear/JW & Left fornix & $1 /$ nil & $\begin{array}{l}\text { Conservative/admitted for } \\
\text { observation only }\end{array}$ \\
\hline $1166020 / 2011$ & 40 & $\begin{array}{l}\text { Self harm glass \& razor } \\
\text { blades insertion/3 }\end{array}$ & tear & $\begin{array}{l}\text { Posterior } \\
\text { fornix }\end{array}$ & 2/nil & EUA \& sutures \\
\hline $1356370 / 2010$ & 28 & Coital/3 & tear & Left lateral & 5/yes EBL $1.5 \mathrm{~L}$ & $\begin{array}{l}\text { Transfused } 2 \text { units packed } \\
\text { cells/EUA/sutures }\end{array}$ \\
\hline $1900866 / 2010$ & 20 & Coital/0 & tear & $\begin{array}{l}\text { Posterior } \\
\text { fornix }\end{array}$ & 2/nil & EUA/sutures \\
\hline $1917464 / 2010$ & 24 & Coital/2 & tear & $\begin{array}{l}\text { Posterior } \\
\text { vagina }\end{array}$ & 4/nil & EUA/sutures \\
\hline $1922962 / 2010$ & 27 & Coital/ 0 & tear & $\begin{array}{l}\text { Lateral } \\
\text { vagina }\end{array}$ & 3/nil & EUA/ sutures \\
\hline $1878266 / 2009$ & 25 & $\begin{array}{l}\text { Consensual insertion } \\
\text { of } \mathrm{FB} / 0\end{array}$ & laceration & $\begin{array}{l}\text { Right vaginal } \\
\text { wall }\end{array}$ & 4/nil & EUA/ sutures \\
\hline
\end{tabular}


the injury may be missed by not performing an adequate clinical assessment because of pain or because of a large blood clot partly obscuring the injury, hence EUA is recommended in such cases. It is important to recognise that some injuries to the upper vagina enter the peritoneal cavity and may injure bowel, bladder or the posterior wall of the uterus. The use of such terms as tear and laceration appears to be imprecise with the extent of the injury more reliably being described by length measurements in centimetres (Table 1). However continued bleeding rather than size of the wound determined whether suturing was required.

Associated non-genital injuries were not found in this study. This is maybe because of the small numbers in the study and the absence of rape leading to vaginal injury in our cohort. Others report that a minority of women sustain genital injuries as a result of rape [8]. Biggs, Stermac and Divinsky (1998) reported that genital injuries were more common in women without prior coital experience [9]. However all of our cases were coitally experienced. In a report of non-genital injuries following alleged rape from Sunderland, New South Wales [10] 68 of 83 (82\%) victims received injuries to limbs, especially the upper limbs, neck, chest, face, back and buttocks.

Cases of accidental and penetrating injuries to the genitals should receive broad spectrum antibiotics and tetanus prophylaxis [3]. In some circumstances offering to enlist the assistance of a psychologist to support the injured woman should be considered to reduce short and long term psychological consequences [1].

\section{CONCLUSIONS}

This study confirms that non-obstetric vaginal injuries are uncommon. The most frequent mechanism of injury was consensual coitus. The low incidence of non-obstetric vaginal trauma and the limiting of the study to a single tertiary hospital may restrict the ability to make generalisations for the results. Although this small study did not find any cases of urethral, anal or bony injury we agree with Dash et al. (2006) when they were discussing non obstetric vulvar injuries that all cases require a thorough assessment for vulvar, vaginal, urethral, anal and bony pelvis injuries [10].

Terms used to describe wounds were not precise with the extent of the wound reported in centimetres being more reliable. However continued bleeding rather than size of the wound determined whether suturing was required.

\section{ACKNOWLEDGEMENTS}

We thank all the staff in the Emergency Department, Royal Brisbane and Women's Hospital for providing care for the women in this study and Jadwiga Chabrowska for searching EDIS for the cases in the study.

\section{REFERENCES}

[1] Koss, M.P. and Figueredo, A.J. (2004) Change in cognitive mediators of rape's impact on psychosis within 2 years of recovery. Journal of Consulting and Clinical Psychology, 72, 1063-1072. doi:10.1037/0022-006X.72.6.1063

[2] Sau, A.K., Dhar, K.K. and Dhall, G.I. (1993) Nonobstetric lower genital tract trauma. Australian and New Zealand Journal of Obstetrics and Gynaecology, 33, 433-435. doi:10.1111/j.1479-828X.1993.tb02132.x

[3] Habek, D. and Kulai, T. (2007) Nonobstetric vulvovaginal injuries: Mechanism and outcome. Archives Gynecology and Obstetrics, 215, 93-97. doi:10.1007/s00404-006-0228-X

[4] Alao, A.O., Yolles, J.C. and Huslander, W. (1999) Female genital self-mutilation. Psychiatric Services, 50, 971.

[5] Favazza, A.R. and Conterio, K. (1989) Female habitual self-mutilators. Acta Psychiatrica Scandanavica, 79, 283289. doi:10.1111/j.1600-0447.1989.tb10259.x

[6] Fallat, M.E., Weaver, J.M., Hertweck, S.P. and Miller, F.B. (1998) Late follow-up and functional outcome after traumatic reproductive tract injuries in women. American Journal of Surgery, 64, 858-861.

[7] Sloin, M.M., Karimian, M. and Ilbeigi, P. (2006) Nonobstetric lacerations of the vagina. Journal of the American Osteopathic Association, 106, 271-273.

[8] Bowyer, L. and Dalton, M.E. (1997) Female victims of rape and their genital injuries. British Journal of Obstetrics \& Gynaecology, 104, 617-620. doi:10.1111/j.1471-0528.1997.tb11543.x

[9] Biggs, M., Stermac, L. and Divinsky, M. (1998) Genital injuries following sexual assault of women with and without prior sexual intercourse experience. Canadian Medical Association Journal, 159, 33-37.

[10] Dash, S., Verghese, J., Nizami, D.J., Awasthi, R.T., Jaishi, S. and Sunil, M. (2006) Severe haematoma of the vulva: A report of two cases and a clinical review. Kathmandu University Medical Journal, 4, 228-231. 